Article

\title{
Circular Economy in Russia: Drivers and Barriers for Waste Management Development
}

\author{
Olga Fedotkina ${ }^{1, *}$, Elena Gorbashko ${ }^{2, *}$ and Natalia Vatolkina ${ }^{3, *}$ \\ 1 Faculty of Finance and Economics, Financial University under the Government of the Russian Federation, \\ Leningradsky prospekt, Moscow 125993, Russia \\ 2 Faculty of Management, Saint Petersburg State University of Economics, Sadovaya str., Saint \\ Petersburg 191023, Russia \\ 3 Faculty of Engineering Business and Management, Bauman Moscow State Technical University \\ (National Research University), 2nd Baumansksys str., Moscow 105005, Russia \\ * Correspondence: fedotkina.olga@list.ru (O.F.); gorbashko.e@unecon.ru (E.G.); vatolkina@bmstu.ru (N.V.)
}

Received: 26 September 2019; Accepted: 17 October 2019; Published: 21 October 2019

\begin{abstract}
Russia is just starting to become a circular and green economy. The development of an efficient national waste management system is a prerequisite for the circular economy (CE). Russian companies are already moving toward adopting more circular business models because it is proven to be a sound business strategy. This strategy facilitates access to new markets, drives innovative solutions, and saves production costs. This paper presents a general understanding of the CE concept. Using practical examples, we show how the Russian government and other stakeholders are providing solutions to advance the development of the waste management system. The paper demonstrates political, legal, and institutional changes implemented through waste management practices and reforms. We introduce four stages of evolution of waste management in Russia and discuss the changing roles of stakeholders in a waste management ecosystem. We conduct a case study of the best available techniques of waste management in leading Russian companies to identify the roles existing in waste management systems (WMS), to allocate responsibilities of each role, and to describe three types of corporate strategies of waste management. The paper is based on the analysis of official public documents and official reports of leading Russian companies.
\end{abstract}

Keywords: waste management; circular economy; environment protection; sustainability; stakeholder roles

\section{Introduction}

In the era of neo-industrialization, sustainable development requires balanced and simultaneous consideration of the economic, environmental, technological, and social aspects of a considered economy, its sector, or individual manufacturing process. It should also consider the interaction between all these aspects [1,2]. A circular economy (CE) contributes positively to reconcile all the aspects, thanks to its underlying rationale, mainly rooted in the environmental and political aspects [3], as well as the economic and business aspects [4]. Industry 4.0 offers enormous opportunities enabling the $\mathrm{CE}$ in which products are reused, remanufactured, and recycled at the end of their lifecycle. The $\mathrm{CE}$ promotes a more appropriate and environmentally sound use of resources to make the economy greener. The CE is characterized by a new business model and innovative employment opportunities $[4,5]$, as well as by improved well-being and evident impacts on the equality within and among generations in terms of both resource use and access.

The roots of the circular economy originated toward the end of the 1960s. The idea of this concept was born with the help of several researchers, businesspersons, and innovators [4-10]. 
However, a few standout academics played a major role in the circular economy development. The circular economy concept evolved from five main schools: industrial ecology, cradle to cradle, performance economy, blue economy, and biomimicry (Figure 1).

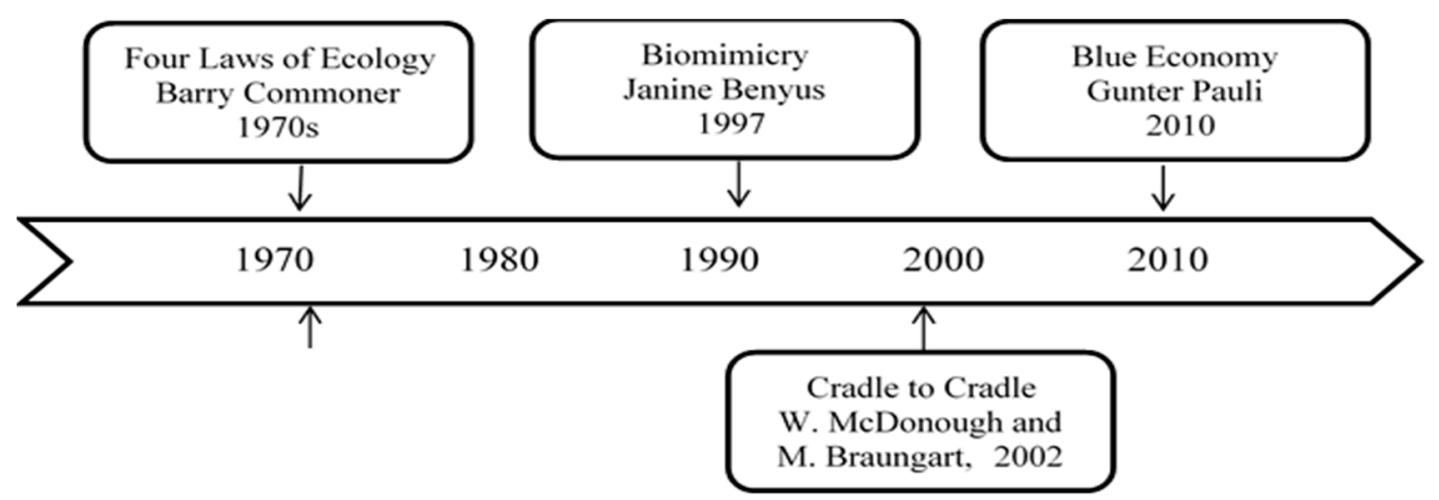

Figure 1. The most important milestones in the development of the circular economy (CE) concept.

However, it was the 2012 report on the circular economy by the Ellen MacArthur Foundation that gave this concept a real promotional boost [11].

According to the Ellen MacArthur Foundation, the circular economy is a regenerative economy, which aims to keep materials and products at their highest usefulness. In other words, the CE concept is almost a waste-free production that aims to reduce waste and pollution.

In 2018, the Global Circularity Report announced that only 9\% of the world economy was circular [12]. Due to the complexity of the sustainable development vision, most often its implementation needs to be supported by innovation designers and intermediaries. They provide services and designs ushering appropriate radical changes in practices, policies, and decision-making tools $[13,14]$.

Many countries adopted the principles of the $\mathrm{CE}$ as part of their future strategies. For example, the $\mathrm{CE}$ is promoted as a top-down national political objective in China, while, in other areas and countries such as the European Union, Japan, United States of America (USA), and Russia, it is a tool to design bottom-up environmental and waste management policies. It means that a major role in waste management systems belongs not to the government but to the different stakeholders involved in waste management systems such as business companies that generate waste or participate in waste management systems, municipalities managing household waste, and non-governmental organizations (NGOs) offering education, promotion, and support in implementation of CE and waste management practices.

The ultimate purpose of the paper is to evaluate to what extent the waste management as a part of the CE is implemented in Russia by companies in different sectors of the economy and if it can solve the issue of reducing the environmental impact of the business economic system in Russia.

The main subject of this paper is waste management implementation practices as the initial stage of implementing the principles of the CE in Russia.

The paper provides a brief theoretical overview of the evolution of the CE concept, its origins, and its relationship with the sustainability and growth patterns that until now challenged the present models of economic development. It summarizes the evolution and current state of state regulation in the field of CE in Russia with special attention to waste management; it also evaluates the experience of implementing the waste management approaches by business companies in Russia based on selected case studies and, as a result, offers a list of roles of waste management system stakeholder roles and waste management strategies. Finally, the paper considers the challenges and opportunities for the waste management in Russia.

The paper is structured as follows: Section 2 (Materials and Methods) provides details about the methods used for the literature review and the main characteristics of the studies selected for this review. This section also lists the companies chosen for the case study of best available techniques in 
waste management in Russia. Section 3 (Results and Discussion) focuses on the implementation of the main milestones of the waste management in the Union of Soviet Socialist Republics (USSR) and Russia. It considers the political, legal, and institutional changes, which are implemented through waste management practices and reforms, namely, abandoning old practices and focusing on separate waste collection. This section also considers the opportunities and challenges of the waste management in Russia. A part of this section is aimed at analyzing recycling policies at the national level. The case study focuses on the recycling and reuse programs implemented in companies from different sectors of the Russian economy. The case study allowed determining the roles and responsibilities of stakeholders in a waste management system, so as to offer types of waste management strategies for minimizing long-term environmental damage which can be used for designing waste management practices in Russian companies according to the state regulations. Finally, Section 4 (Conclusions) highlights the key findings of the study and presents some limitations and recommendations for future research, as well as policy implications and recommendations for future improvement of the CE in Russia.

\section{Materials and Methods}

This study used a qualitative research method that was deployed in three stages.

Stage 1 was a literature review of the concepts, successful factors, and barriers related to the implementation of the CE in the USSR and Russia.

Stage 2 was based on Stage 1 and provided a conceptual framework for integrating and evaluating the evolution of waste management government regulation and control between 1970 and 2019. This stage was based on a review of state laws, state development programs, and initiatives with the focus on goals of waste processing and distribution of roles between waste management system stakeholders. The main purpose of this stage was to extract the information contained in the document, preprocess this information, and then use it to study the problem. Two official electronic databases of public law in Russia, namely, Garant and Consultant Plus, were used for searching, selecting, and analyzing regulatory documents.

Finally, Stage 3 was based on a case study of best available techniques in leading Russian companies to reveal trends in the implementation of the $\mathrm{CE}$ and waste management principles introduced by government regulations. The logic behind the case study was to choose the cases that are likely to be replicated or extended as they contain the best practices of waste management performed by companies in the sectors of economy that either are the main waste generators or play specific roles in waste management system [15]. Five companies from different sectors of the Russian economy were chosen for the case study (Table 1).

Table 1. Companies selected for the case study of best available techniques in waste management in Russia.

\begin{tabular}{cccc}
\hline & Sector of Economy & $\begin{array}{c}\text { Number of } \\
\text { Employees }\end{array}$ & $\begin{array}{c}\text { Revenue, 2017 Millions } \\
\text { of Russian Rubles }\end{array}$ \\
\hline $\begin{array}{c}\text { Public Joint Stock Company } \\
\text { (PJSC) “Gazprom” }\end{array}$ & Oil and gas industry & Over 26,000 & $6,524,711$ \\
Public Joint Stock Company & Petrochemical industry & Over 26,000 & 454,619 \\
(PJSC) “Sibur” & Transport and logistics & Over 735,000 & $1,697,553$ \\
Russian Railways (RZD Holding) & $\begin{array}{c}\text { Production of office supplies } \\
\text { OPTICOM Ltd }\end{array}$ & 554 & 7100 \\
EVRAZ plc (public company) & Metallurgy and coal mining & 70,186 & 623,535 \\
\hline
\end{tabular}

The units of analysis were the best available techniques in waste management that a company already performs. The data were collected from open sources-official websites, printed reports, and business media publications. 


\section{Results and Discussion}

\subsection{Global Movement toward the Circular Economy}

The report titled "What a Waste 2.0: A Global Snapshot of Solid Waste Management to 2050" predicts that global annual waste generation will increase from 2.01 billion tons in 2016 to 3.5 billion tons in 2050, as nations develop economically, as well as urbanize and increase their population.

According to the United Nations (UN), solid waste generation correlates with national income. In other words, wealthy countries have more household waste per capita (Figure 2). However, high per capita waste is accompanied by high levels of waste recycling in the European Union. In a World Bank study published in the early 2010s, the Russian Federation was classified as an upper-middle-income country. By the year 2025, waste generation rates were estimated at $1 \mathrm{~kg}$ per day per capita. It is projected that waste generation rates will increase by about a quarter. Russia's waste generation rates were lower compared to the USA (2.6), the Netherlands (2.1), New Zealand (3.6), Norway (2.8), and Switzerland (2.6) [16].

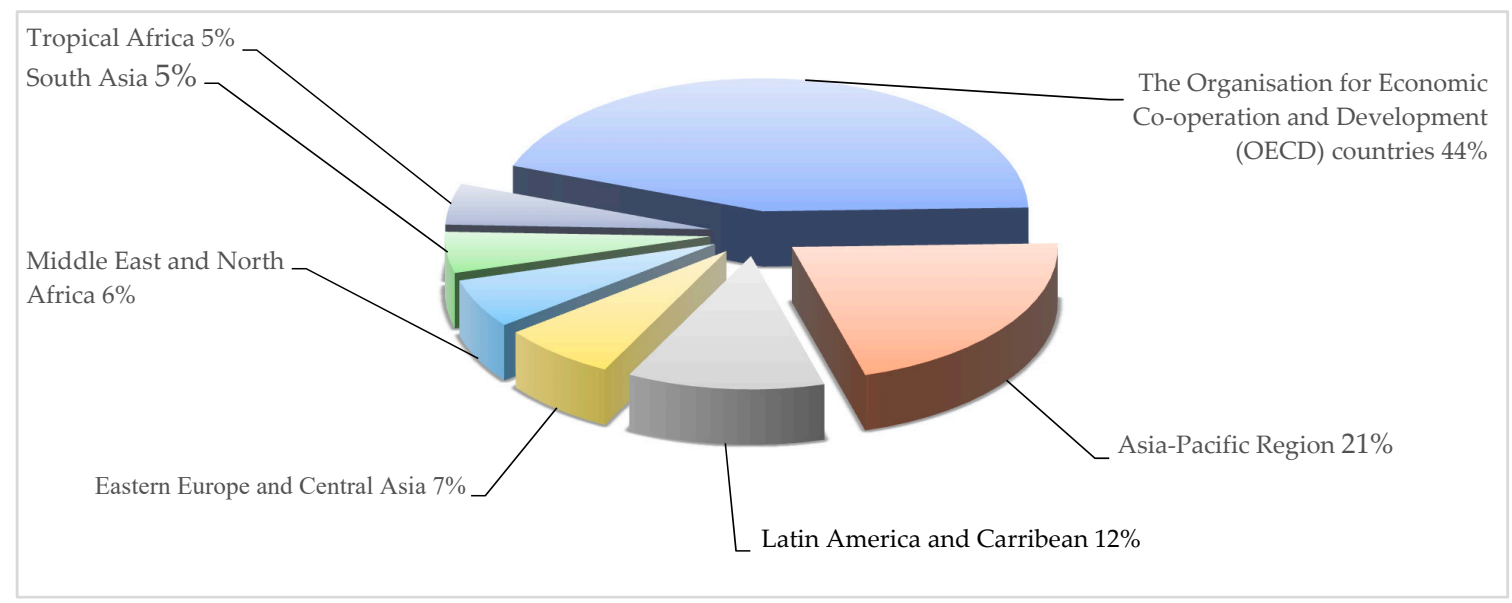

Figure 2. Distribution of solid waste production regions [16].

The combined high-income countries generate $34 \%$ of the world's waste, although they only account for $16 \%$ of the global population.

Low-income countries collect only about half of the waste generated in cities and one-quarter of the waste generated in rural areas. Furthermore, over $90 \%$ of waste is mismanaged by being either burned or openly dumped. In low-income countries, only $4 \%$ of waste is recycled. In high-income countries, over one-third of the waste is recovered through recycling and composting [17]. Proper waste management is essential for building sustainable and livable cities, but it remains a challenge for many developing countries and cities. Effective waste management is expensive, often comprising 20-50\% of municipal budgets. In low-income countries, waste management accounts for nearly $20 \%$ of municipal budgets, on average. In middle-income countries, solid waste management typically accounts for more than $10 \%$ of municipal budgets, and it accounts for about $4 \%$ in high-income countries.

Costly and complex waste operations must compete for funding with other high-priority needs such as clean water and other utilities, education, and healthcare. Local authorities often administer waste management with limited resources and limited capacity for planning and contract.

In a bid to capitalize on such opportunities, public- and private-sector decision-makers around the world set out policies on the CE (Figure 3); however, these policies vary in how they refer to the CE and how they approach it [18]. 


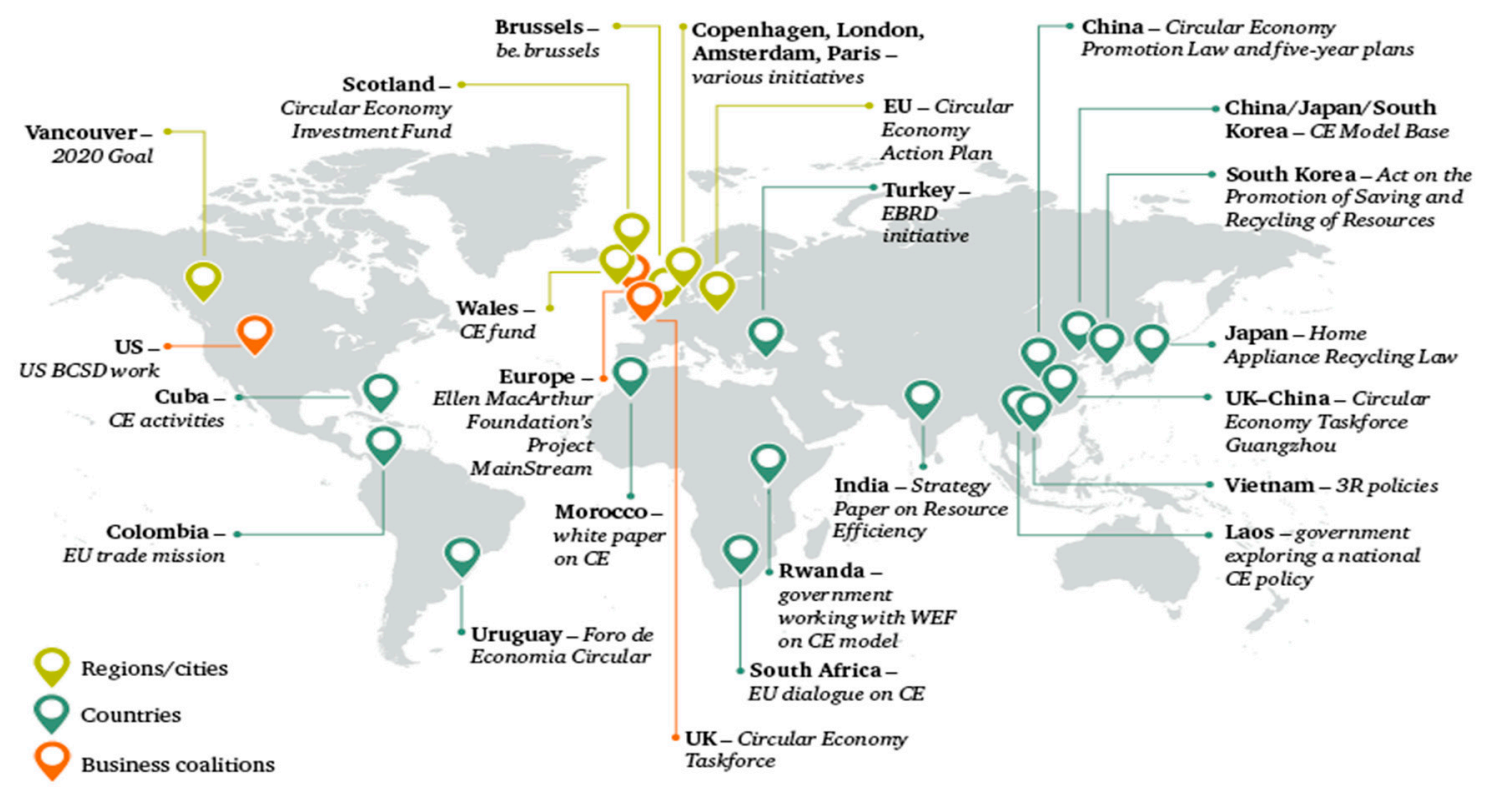

Figure 3. Circular economy activity around the world [18]. CE = Circular Economy, EBRD = European Bank for Reconstruction and Development, USBCSD = United States Business Council for Sustainable Development, WEF = World Economic Forum.

The CE is about expanding the practice of using waste as a secondary resource. The CE is also about using intelligent design and engineering to enable products to have multiple lifecycles and be reused. Eventually, the CE affects not only waste management policy but also product design standards and extended producer responsibility.

\subsection{Current Waste Management Situation in Russia}

As required under the Federal Waste Classification Catalogue, approved by Ministry of Natural Resources of the Russian Federation (RF MNR) Order No. 786 of 2 December 2002, and the Attachment to RF MNR Order No. 663 of 30 July 2003, "Amendment to the Federal Waste Classification Catalogue" (FWCC), wastes are divided into five hazard classes (Table 2), whereby hazard class 1 wastes are the most hazardous and hazard class 5 wastes are considered to be non-hazardous.

Table 2. Russian waste classification system.

\begin{tabular}{|c|c|c|c|}
\hline $\begin{array}{l}\text { Hazard } \\
\text { Class }\end{array}$ & Hazard Description & Waste Stream Project Examples & $\begin{array}{l}\text { International } \\
\text { Definition }\end{array}$ \\
\hline 1 & Extremely hazardous & $\begin{array}{l}\text { Fluorescent light bulbs containing mercury, } \\
\text { activated carbon contaminated with mercury } \\
\text { sulfide }\end{array}$ & \multirow[t]{3}{*}{ Hazardous } \\
\hline 2 & Highly hazard & $\begin{array}{l}\text { Concentrated acids, alkalines, halogenated } \\
\text { solvents, lead-acid batteries, dry batteries, etc. }\end{array}$ & \\
\hline 3 & Moderately hazard & $\begin{array}{l}\text { Used lubrication oil, oily sludge, oily rags, used oil } \\
\text { filters, non-halogenated solvents, paint wastes, etc. }\end{array}$ & \\
\hline 4 & Low hazard & $\begin{array}{l}\text { Domestic trash, nonferrous metal scrap, certain } \\
\text { chemicals, certain construction waste, treated } \\
\text { sewage sludge, treated medical wastes, } \\
\text { water-based drilling mud, etc. }\end{array}$ & \multirow[t]{2}{*}{ Non-hazardous } \\
\hline 5 & $\begin{array}{l}\text { Practically } \\
\text { non-hazardous }\end{array}$ & $\begin{array}{l}\text { Inert wastes: plastic, ferrous metal scrap, inert } \\
\text { construction wastes, food waste, brushwood, } \\
\text { non-treated wood waste }\end{array}$ & \\
\hline
\end{tabular}


This classification system is based on a set of parameters that take into account both the impact of wastes on the environment and toxicity parameters, which are significant for assessing the potentially harmful effects of waste on human health.

This classification system is somewhat different from those applied in other countries, such as member states of the European Union (EU), where wastes are often simply classified into two groups: "hazardous" or "non-hazardous".

The regulations in Russia permit disposing of some hazard class 3 and all hazard class 4 (with a few exceptions) wastes into municipal solid waste landfills. This is subject to an application and permission procedure, whereby the waste generator must substantiate the approach taken for disposal.

The current practice of waste management in Russia is characterized by a negative impact on the environment and human health, as well as inefficient use of material and energy resources.

According to the Federal Service for Supervision of Natural Resources (Rosprirodnadzor), 5-7 billion tons of waste is generated annually in the country. In 2018, a major part of waste (66\%) was attributed to the extraction of fuel and energy minerals (mainly coal enterprises), $22.6 \%$ was attributed to mining of metal ores, $1.9 \%$ was attributed to metallurgy, $0.6 \%$ was attributed to the chemical industry, and $8.9 \%$ was attributed to other sectors, including housing and communal services. Municipal solid waste (MSW) makes up 1-2\% of all waste (according to Russian State Service of Statistics, 274.4 million $\mathrm{m}^{3}$ or $0.88 \%$ of the total amount of waste generated in Russia in 2017) [19]. More than $90 \%$ of waste in Russia is brought to landfills. The country has a total of 1000 municipal solid waste landfills, 15,000 authorized and 17,000 unauthorized landfills, and 13,000 unauthorized waste disposal sites with a total surface of four million hectares. This value annually increases by $300-400$ thousand hectares. Moreover, $50-70 \%$ of the current infrastructure is obsolete, and many formal collection services do not extend to small towns and villages in Russia [20]. Figure 4 shows the composition of waste disposed of in landfills.

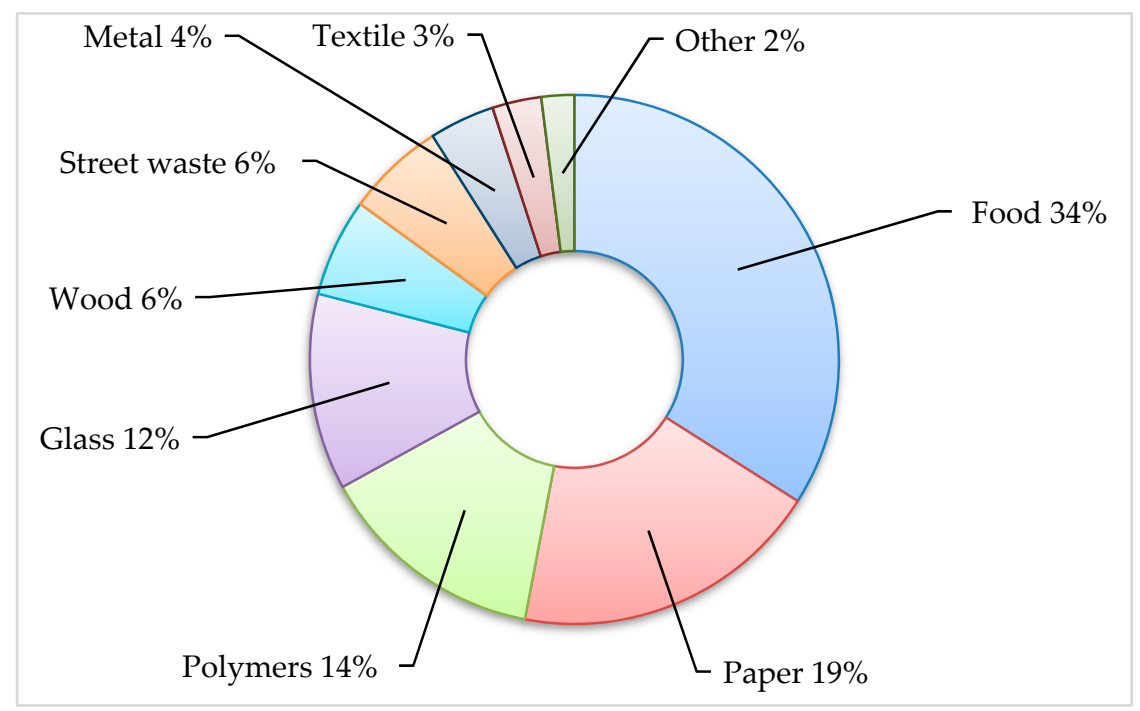

Figure 4. Russian landfill waste composition [21].

Despite a significant fraction of wastes suitable for processing, the level of processing of solid waste in Russia is extremely low. Although a variety of reprocessing and recycling methods for MSW exist, most MSW ( $\sim 95 \%$ in Moscow) is discarded without preliminary sorting in open landfills [22]. Whereas the EU on average recovers approximately $40 \%$ of its waste as reusable materials, and $20 \%$ as energy, Russia currently recovers only $4 \%$ of solid waste in total. Instead, $96 \%$ of solid waste is disposed of (Figure 5). 


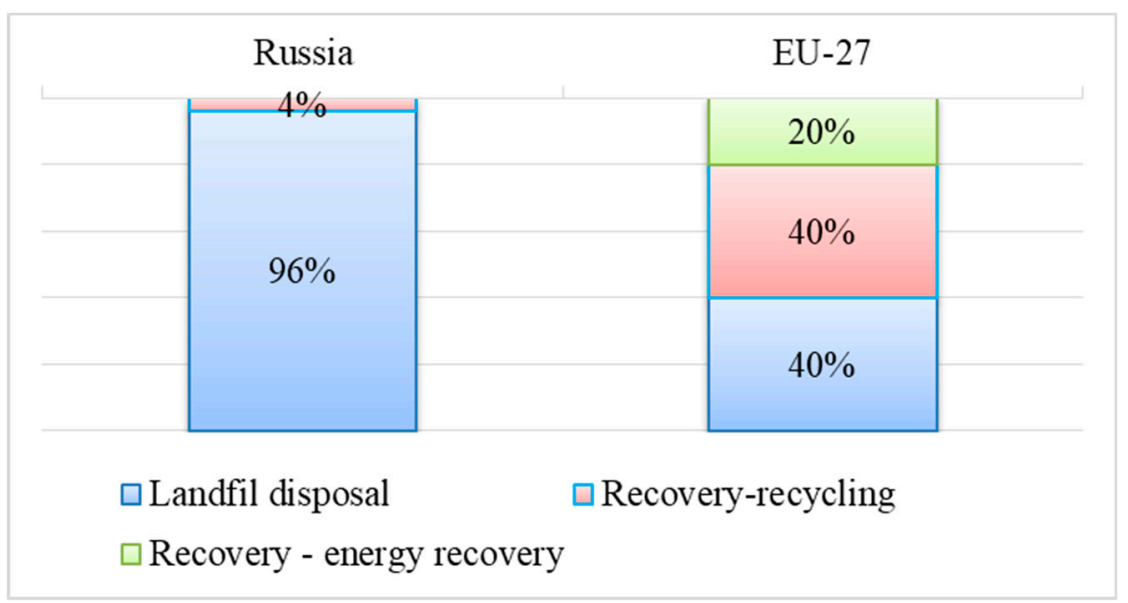

Figure 5. Comparative analysis of waste treatment [23].

The figures show the growing amount of solid waste brought to landfills without sufficient treatment. This creates negative environmental, social, and economic impacts.

1. The negative environmental impacts are soil, air, and water pollution generated by landfills, as well as a negative impact on biodiversity and phytosanitary safety in a local community. The situation is getting worse because there are ownerless waste disposal facilities and objects of past environmental damage present in many regions.

2. The social impacts include decreased life quality for the population of the neighborhoods located nearby landfills due to bad smell and visual impressions, as well as concerns for health, which may lead to migration of people. The growing number of landfills and the growing amount of waste lead to increasing social tension in some regions of Russian Federation.

3. The economic impacts are the occupation of land for landfills, as well as the waste of non-renewable resources.

There are several problems that contribute to the problem of the growing amount of waste in Russia, including insufficient infrastructure and market incentives for waste processing, the lack of economically viable technologies for processing some types of production waste, the lack of waste disposal facilities that meet the requirements of environmental and sanitary legislation, the lack of a civilized market of secondary material resources, the lack of waste sorting culture and infrastructure both in households and in business, and the lack of responsible production and consumption culture with an excessive amount of packaging going to waste, whereby items that could be repaired, recycled, or reused are thrown away to be buried in landfills.

Waste is not only an environmental problem. There is also a problem related to the ability or inability of governments, individuals, and waste disposal firms to keep up with the task of managing waste and protecting the environment. Solutions are possible, but they require political will and substantial investment.

\subsection{Background of CE in Russia}

To assess the situation in Russia, it is important to emphasize that the foundations of the circular model of the economy were already laid out and implemented in the USSR. Some waste types (firstly rags and wastepaper, and then other fractions of municipal solid waste and almost all types of industrial waste) are traditionally considered as secondary resources, and not as environmental pollutants. From the birth of the Soviet Union in the 1920s until its collapse in 1991, a positive trend continued to involve waste in a further production cycle [24]. Five groups of recyclable materials for the national economy were formed: wastepaper, polymeric materials, tires, textiles, and broken glass. Accordingly, the state policy and legislation in this area were formed. The instrument of state policy was standardization, which influenced the product design: its long lifecycle and stable quality. Unification in the industry 
created the conditions under which the transition to re-production could be carried out today. In the Soviet Union, the centralized state planning and rationing of the level of collection and processing of the most important types of secondary raw materials with the help of state and sectoral programs on secondary material resources were widely used.

In the Soviet Union, households and companies actively collected wastepaper, glass, and scrap metal, because a dedicated production infrastructure was created for the collection and industrial processing of the main types of secondary raw materials throughout the country. The Soviet government developed large-scale recycling programs during the 1970s. During the 1980s, almost 30\% of all paper used and around $45 \%$ of all glass bottles were recycled [25]. Furthermore, consumers routinely visited glass recycling centers to return glass bottles. Since 1986, a General Provision was introduced that "the organization responsible for the development of new materials or products must simultaneously develop a technology for their reuse or recycling after the end of their service life or operation, providing for the creation of appropriate facilities at the same time as the creation of facilities for the production of materials or products". Thus, back in the 1980s, the Soviet Union introduced the elements of extended producer responsibility 10-20 years before it was done in Europe. Thus, in the Soviet Union, a quite efficient and robust central waste management system was built even earlier than in many European countries. Its operation was possible only under conditions of a planned economy, although some approaches were quite successful and could be adopted for the CE concept for the EU and Russia.

During the 1990s, as the Soviet Union collapsed, most of its social programs, including recycling, also collapsed. As subsidies and official support were withdrawn, the Russian system of collecting scrap metal, wastepaper, recycled textile, and glass was abolished.

\subsection{Reforming Waste Management in Russia}

Post-Soviet Russia faced difficulty in developing a strong, consistent legislative framework for reforming its waste management. The reform of waste management was performed in three stages.

The first stage of waste management reform took place in 1996 and 2000 as a federal target program "Waste" [26], one of the tasks of which was "to create a regulatory and technological framework for the implementation of a unified state policy in the field of waste management at all levels of management". It was assumed that up to $80 \%$ of the costs for the implementation of the program would be covered by budget funds, and the remaining $20 \%$ would be provided with profit from the sale of secondary raw materials. However, insufficient support was provided to the reform, and its goals were not achieved.

In 1998, the law 89-FZ "on production and consumption waste" [27] was adopted with the purpose to bring the solid waste management practices into the legal space. Waste disposal registers were created. They contained information about all legal places of waste storage.

In 2004, the second stage of the reform started employing a different approach, delegating responsibility for solid waste management to the municipal level. This was a part of a general reform to encourage localities to resolve their own problems. However, for MSW and other issues, municipalities generally lacked the financial resources, experience, and investment opportunities to create the infrastructure needed to resolve the issues at hand. Moreover, in 2008, compulsory licensing was abolished, with the exception of hazardous class waste management.

As a result, between 2000 and 2014, disposal into Russian landfills nearly doubled, from 151.2 million to 284.3 million cubic meters.

From 2010 to 2014, a package of amendments to FZ-89 was developed. The law introduced the concepts of processing (sorting) and processing for recycling and creating infrastructure for this. In 2016, the licensing of any activity related to the collection and processing of waste was introduced, as well as the concept of extended producer responsibility (EPR), i.e., companies that produce packaged goods should independently engage in processing or should pay an environmental fee to the state budget.

In 2019, the key point of the reform — the transition to a new system of handling MSW—came into force. According to the law N 503-FZ "on modification of the Federal law 'on production and consumption waste' [28] and separate legal acts of the Russian Federation", in all regions of the country, 
except Moscow and St. Petersburg (they were given a delay until 2022), regional operators earned the right to control all methods of waste management from a garbage tank to the range or plant on processing. Of great importance is the digitalization of the process; there are territorial schemes of waste management-electronic maps, which marked all the official container sites and infrastructure facilities-landfills, marshaling yards, and processing plants. Control over the export of waste moved to an electronic platform; waste disposal vehicles are to be equipped with trackers with the GLONASS system, garbage is to be weighed at the sorting and landfills, and contracts and payment for them are made electronically.

The new waste management concept, according to the main instructions of the President of Russia to the Russian Government, includes the following:

- MSW management based on a closed-cycle economy;

- Stimulate production from secondary material resources;

- Implement a separate collection of MSW;

- Develop eco-industrial parks;

- Create a unified state information system for waste accounting;

- Education of the public for ecological awareness (Figure 6).

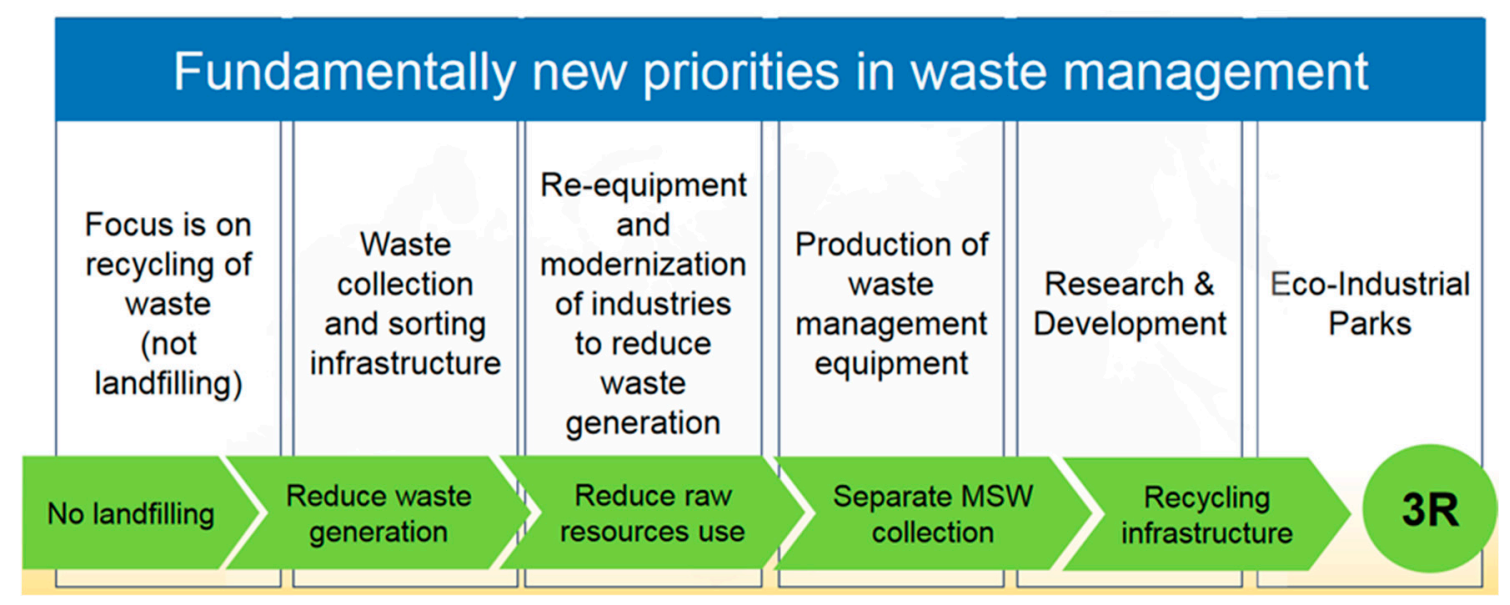

Figure 6. Priorities of "strategy for development of industry for sorting, recycling, and treatment of waste for the period until 2030" [29].

Revision of the waste management regulation evolution allowed us to identify five stages with the specific features covering government policy, infrastructure, limitations, and stakeholder involvement (Table 3).

The evolution shows the changing role of all stakeholders: government, business, households, and municipal administration. It may seem that waste management is downshifted to the municipal level leaving federal authorities behind. However, we can see that the reform strengthens the role of all stakeholders identifying their place in the regional waste management ecosystem. The new stage should bring new funding rules with the decentralization of investment decisions and funds necessary to develop local infrastructure. The municipal facilities define the vital activity of a city or a town. To ensure it, socio-economic development plans are elaborated. The environmental safety of the territory, including the sphere of collection, removal, and disposal of municipal solid waste, is an integral part of the socio-economic development of a city. The city has to have a system that allows tracking the overall condition of waste collection, as well as transport and disposal systems, and it should constructively respond to changes and threats, providing friendly and comfortable accommodation facilities [30-32]. 
Table 3. Evolution of waste management practices in Russian Federation between 1970 and 2019.

\begin{tabular}{|c|c|c|c|c|}
\hline $\begin{array}{l}\text { Specific Features of } \\
\text { the Waste } \\
\text { Management } \\
\text { Evolution }\end{array}$ & $\begin{array}{l}\text { 1970-1990 Soviet Period: } \\
\text { Roots of Circular } \\
\text { Economy }\end{array}$ & $\begin{array}{l}\text { 1990-2004 Post-Soviet } \\
\text { Collapse }\end{array}$ & $\begin{array}{c}\text { 2004-2019 Waste Management } \\
\text { Consciousness }\end{array}$ & $\begin{array}{l}2019 \text { The Emergence of Responsible } \\
\text { Waste Management }\end{array}$ \\
\hline Government policy & $\begin{array}{l}\text { Government implements } \\
\text { financed state programs of } \\
\text { waste collection and } \\
\text { recycling }\end{array}$ & $\begin{array}{l}\text { The minimum regulation } \\
\text { that does not work }\end{array}$ & $\begin{array}{l}\text { Development of state policy and } \\
\text { regulations for waste recycling and } \\
\text { environmental protection; focus on } \\
\text { infrastructure development }\end{array}$ & $\begin{array}{l}\text { Waste management turns from separate } \\
\text { tools to concept with focus on recycling } \\
\text { (not landfilling) }\end{array}$ \\
\hline $\begin{array}{c}\text { Municipal } \\
\text { administration }\end{array}$ & No specific role & No specific role & $\begin{array}{l}\text { Delegation of responsibility for solid } \\
\text { waste management to the municipal } \\
\text { level }\end{array}$ & $\begin{array}{l}\text { Regional operators earned the right to } \\
\text { control all methods of waste } \\
\text { management from a garbage tank to the } \\
\text { range or plant on processing }\end{array}$ \\
\hline Business & $\begin{array}{l}\text { Responsible for collection } \\
\text { and recycle/re-use of } \\
\text { several types of industrial } \\
\text { waste }\end{array}$ & $\begin{array}{l}\text { Almost no responsibility } \\
\text { and no incentives for the } \\
\text { solid waste recycling or } \\
\text { re-use; the main practice is } \\
\text { landfilling }\end{array}$ & $\begin{array}{l}\text { Extended producer responsibility } \\
\text { (EPR)— companies that produce } \\
\text { packaged goods should independently } \\
\text { engage in its processing or pay an } \\
\text { environmental fee to the state budget }\end{array}$ & $\begin{array}{l}\text { Responsible for the management of } \\
\text { industrial waste, environmental fees, the } \\
\text { active development of business } \\
\text { initiatives for solid waste re-use }\end{array}$ \\
\hline Household & $\begin{array}{l}\text { Separate waste collection } \\
\text { routine culture }\end{array}$ & No incentive, no role & $\begin{array}{l}\text { Separate waste collection initiatives for } \\
\text { the population are introduced in } \\
\text { several regions; still little incentive and } \\
\text { almost no role }\end{array}$ & $\begin{array}{l}\text { Still little incentive; development of } \\
\text { public initiatives for waste reduction and } \\
\text { responsible consumption; new high fees } \\
\text { for municipal services for waste } \\
\text { management }\end{array}$ \\
\hline Infrastructure & $\begin{array}{l}\text { Exists everywhere for } \\
\text { collection, sorting, and } \\
\text { recycling }\end{array}$ & Landfills & $\begin{array}{l}\text { Landfills, several plants for burning of } \\
\text { waste and several recycling plants }\end{array}$ & $\begin{array}{l}\text { Fast development of plants for burning of } \\
\text { waste and several recycling plants; still } \\
\text { lack of infrastructure for the separate } \\
\text { waste collection; emergence of digital } \\
\text { infrastructure for waste processing. }\end{array}$ \\
\hline Limitations & $\begin{array}{l}\text { Only part of the waste is } \\
\text { recycled such as glass } \\
\text { bottles, metal scrap, and } \\
\text { scrap paper }\end{array}$ & $\begin{array}{l}\text { Waste management was } \\
\text { limited to collection and } \\
\text { landfill disposal of solid } \\
\text { waste; landfill ownership } \\
\text { became a corrupt business }\end{array}$ & $\begin{array}{l}\text { Unstructured policy, investments are } \\
\text { not enough, the role of business and } \\
\text { people is very low }\end{array}$ & $\begin{array}{l}\text { Incentives for business are still } \\
\text { insufficient; infrastructure for separate } \\
\text { household waste collection is insufficient }\end{array}$ \\
\hline
\end{tabular}


Currently, "green" initiatives and pilot projects of the CE are developing in Russia with state support. The best results were achieved at the level of big businesses and state corporations where the production process covers the entire value chain. A new environmental safety instrument for larger installations, namely, integrated environmental permits (IEP), based on best available techniques (BAT), was introduced in Russia at the beginning of 2015. Similar to the EU experience, Russia is planning to develop a large number (47) of reference books (BREFs) on best available techniques. In Russia, these documents form an integral part of the national standardization system. They are being formed by Sectoral Technical Groups of the National BAT Bureau functioning under the Federal Agency for Technical Regulation and Metrology (Rosstandard). By 2021, all Russian enterprises should switch to BAT.

The government can provide critical support for the CE initiatives and innovative business models including support for research, enabling demonstration programs, and providing economic incentives for pilots and start-ups (for example, through preferential lease and business tax rates).

If Russia optimizes its MSW management policy and implements modern technologies, it could fully shift toward an environmentally friendly MSW management system and be able to recover up to $45 \%$ of waste by 2025 . As a result, more than 200 million tons of MSW will be recovered to raw materials and energy instead of landfilling by 2025 [33].

Best Available Techniques: A Case Study of Leading Russian Companies

As a result of monitoring how Russian enterprises implement the CE and WMS practices, we identified five organizations from different sectors of economy including the main waste generators: energy resources mining and metallurgy companies, as well as two service sector companies-one large and one small. The case selection allowed us to demonstrate the typical strategies of Russian companies implementing the CE concept and WMS. This analysis allowed solving the following tasks:

- Identify stakeholders and describe the roles they can play in the waste management system;

- Define the main criteria of the strategy selection and study the specific features of WMS implemented in different organizations;

- Determine the basic WMS business strategies;

- Substantiate general approaches to the choice of WMS business strategies.

1. Public Joint Stock Company (PJSC) SIBUR is the largest vertically integrated petrochemical company in Russia. The main strategic objective of PJSC SIBUR is to reduce the negative environmental impact of its production.

PJSC SIBUR implements its model "green wings", which introduces the 3R principles (reduce, reuse, recycle) throughout the value chain—from production to waste processing (Figure 7) [34].

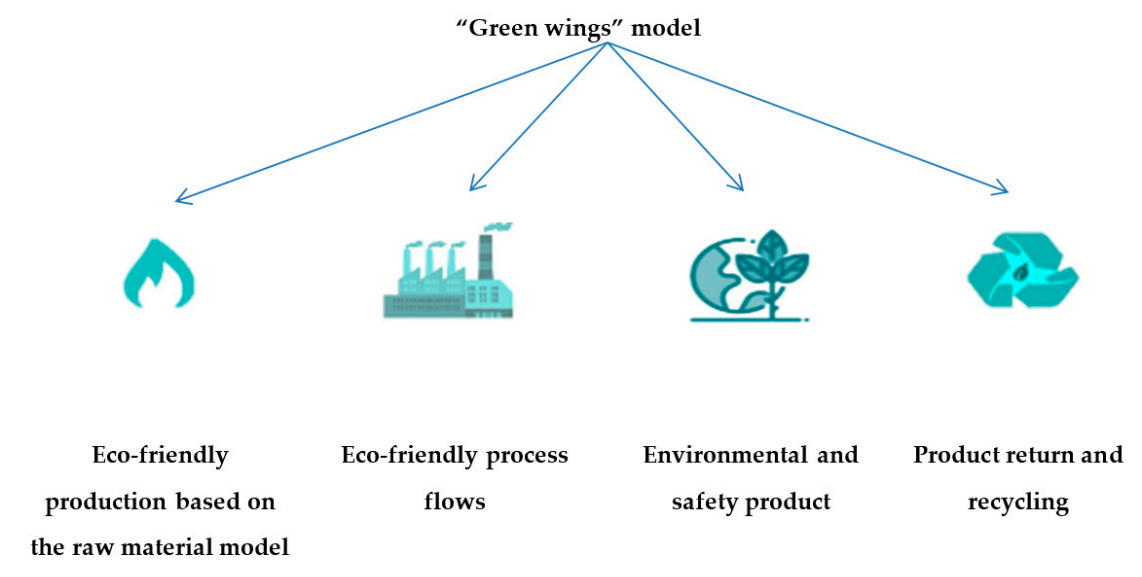

Figure 7. “Green wings" Initiative of Public Joint Stock Company (PJSC) SIBUR. 
The company's green goals include deep processing of associated petroleum gas and fatty fractions of natural gas instead of non-environmental combustion, which prevents the emission of seven million tons of pollutants annually, as well as the use of advanced environmentally friendly technologies at all stages of value creation and commitment to the principles of environmental responsibility, the growth of petrochemical product output because it is more environmentally friendly compared to similar materials in terms of lifecycle, and the promotion of the CE principles and recycling of polymer materials through the collection and recycling of plastic bottles. PJSC SIBUR, together with Wilson, presented the first eco-friendly basketball, the production of which was done using plastic from recycled bottles. It became the official ball of the VTB bank United League championship in the new season.

Along with the implementation of 3R technologies in the value creation chain, PJSC SIBUR actively supports Russia's transition to the CE principles through the following initiatives:

- Participation in the Russian national project "Sort It Right". The purpose of the project is to create an association of public organizations, businesses, government agencies, and municipal authorities, as well as other organizations and citizens of Russia, in order to develop and implement the best new effective practices of separate solid waste collection, and to promote and teach environment protection and the proper disposal of waste for the wider audience;

- Support of initiatives to install containers and automatic machines for separate solid waste collection in Moscow, including the promotion of public initiatives through social networks, the blogosphere, and popular media;

- Membership of the Plastics Europe Association, in which the world's leading manufacturers pay special attention to the implementation of the CE principles in the field of plastics;

- Membership in the Charter of Responsible Care in 2015, which implies adherence to standards in the field of environmental protection, environmental safety, work with society, and the business environment;

- Implementation of the "green office" concept (separate collection of garbage in public areas, installation of motion sensors in public areas in order to save energy, office stationery made of secondary raw materials, etc.).

PJSC SIBUR pays special attention to the projects aimed at raising environmental consciousness and environmental responsibility of children and young people, such as lectures on the circular economy for students, a joint project of PJSC SIBUR and the Tobolsk complex scientific station (TCNS) "ECOTRAIL SIBUR", popular science films for the major Russian TV channels, a project to develop a mobile application about the circular economy (together with students of the gymnasium of the Moscow State University), research projects in the field of green flame retardants, and a clean hexamer.

The case study revealed that PJSC SIBUR sees its role as a generator of eco-friendly products that help to reduce waste from other industries, as well as recycle its own waste and introduce eco-friendly process flows. However, it also takes on the responsibility of education and promotion of CE principles and approaches, investment in relevant infrastructure, and involvement in public and sectoral initiatives in the field of CE. PJSC SIBUR follows three out of five priorities of "strategy for development of industry for sorting, recycling and treatment of waste for the period until 2030" (Figure 5)—recycle waste, reduce waste, and reduce raw resources use.

2. Global energy company PJSC Gazprom also declared its commitment to the principles of sustainable development and environmentally oriented development of the oil and gas industry. PJSC Gazprom seeks to reduce the amount of waste generated in production processes and their negative impact on the environment by introducing new technologies or modernizing equipment in all areas of activity—production, transport, and especially in oil refining.

In 2016, PJSC Gazprom developed a drilling waste management concept to reduce environmental risks and construction costs. The concept takes into account the infrastructure of the fields developed, existing technologies for neutralization and disposal of drilling waste, technical and economic indicators, 
methods of construction of wells (granary and pitless drilling), injection of waste into the reservoir, and remote deposits.

During 2017, Gazprom Group put into operation 29 waste disposal and recycling facilities with a capacity of 9.28 thousand tons/year. Four landfills for utilization, neutralization, and disposal of industrial, household, and other waste with a capacity of 2.19 thousand tons/year were put into operation.

In 2017, PJSC Gazprom became, for the sixth time, the best Russian energy company in the field of corporate climate reporting and strategies to reduce greenhouse gas emissions in the ranking of the international Carbon Disclosure Project. PJSC Gazprom supports and improves the corporate environmental management system based on the requirements of the ISO 14001 standard. It also conducts industrial environmental control and monitoring, as well as assesses the environmental impacts [35].

PJSC Gazprom is focused on two priorities of "strategy for development of industry for sorting, recycling and treatment of waste for the period until 2030" (Figure 5)—reduce waste and reduce raw resources use through re-equipment and modernization.

3. Russian Railways (RZD Holding) applies "green solutions" and eco-logistics in the following areas: air protection, noise protection, use and protection of water resources, waste management, and equipment revamping. In the report of the International Energy Agency "The Future of Railways" (New Delhi, January 2019), Russian Railways are recognized as the most energy-efficient railway company in the world, taking into account the energy consumption per ton-kilometer of freight traffic [36].

An important area of RZD Holding is production waste management. Broken rubble is used for manufacturing of asphalt in cooperation with the Russian Highways State Company (Avtodor); worn concrete sleepers are destroyed with special equipment, whereby the chips can be reused in the construction works. Wooden sleepers are used as fuel, for example, for municipal boiler-houses. Also, RZD Holding, together with United Nations Industrial Development Organization (UNIDO), is implementing a project on the destruction of oils and equipment containing persistent organic pollutants, as well as on the purification of transformer oils in operating transformers, and the elimination of equipment containing polymer bonded explosivesat the expense of the global environment facility with the co-financing of RZD Holding. This project is a pilot in Russia in the framework of the Stockholm Convention. Its results will be disseminated for other industries.

Since 2014, RZD Holding implemented a project on separate waste collection in the company's office buildings, administrative and domestic premises, and railway stations throughout the Russian Federation.

RZD Holding is a member of the commission for environmental culture and education of the federal environmental council under the Ministry of Natural Resources of Russia. It actively participates in the activities of the commission for environmental education of children and youth, and promotion of respect for nature.

In 2019, RZD Holding placed "green" Eurobonds to finance projects to protect the environment, for $€ 500$ million, with a coupon rate of $2.2 \%$ and a maturity of eight years [37]. The organizers of the placement are J. P. Morgan, Unicredit, and VTB capital.

In Russia, such securities are still rare; a similar issue was placed in December 2018 by the company "KhMAO (Khanty-Mansy Autonmous Okrug) resource saving". It attracted 1.1 billion rubles for the creation of a landfill for the placement and treatment of solid municipal waste in the Khanty-Mansiysk region [38].

The case study revealed that RZD Holding, due to the specifics of its operations, is focused mostly on waste recycling and decreasing pollution, but the company also takes on the responsibility of assisting in the penetration of waste sorting practices in different regions, as well as participating in promotional and educational initiatives. 
4. Evraz is an international vertically integrated metallurgical and mining company with assets in the Russian Federation, USA, Canada, Czech Republic, Italy, and Kazakhstan. It is one of the largest steel producers in the world. Evraz's activities inevitably involve the generation of waste such as waste rock, waste ore, and dumps left over from the processing of ore and enriched products. The company's ultimate goal is to reduce the amount of waste they produce and manage it efficiently and safely. To minimize the amount of waste, the company improves technological processes and improves the quality of products. They also reuse some types of waste in future activities, such as steel production, land restoration, road or dam construction, and for heating. Waste not used in current activities is safely stored and further involved in production.

Evraz as a waste generator seeks to comply with two priorities of "strategy for development of industry for sorting, recycling and treatment of waste for the period until 2030" (Figure 5)—reduce waste and reduce raw resources use through re-use of waste.

The limitations of the CE approach of Evraz is that it involves only non-mining waste. In line with Evraz's five-year Environment policy goals, the company will recycle $95 \%$ of its waste every year, excluding mining waste and by-products. In 2018, the recycling rate was $111.3 \%$, as waste from old landfills was recycled. However, as a result of this, Evraz enterprises lost the opportunity to reuse the recyclable waste stored there. Processing of previously placed metallurgical slag and materials allows Evraz to keep the recycling rate above $100 \%$.

The group uses non-hazardous mining waste to restore land and build dams and roads; in 2018, $26.7 \%$ (62 million tons) of waste was, thus, reused [39].

5. At the level of medium-sized businesses, one of the greatest successes in implementing the CE ideas belongs to the company OPTICOM Ltd., working in the segment of consumables and household goods for business. The company is focused on creating a closed cycle of production, consumption, processing, and reuse of its products. OPTICOM Ltd. analyzes the product lifecycle and selects options with a minimal environmental footprint, taking into account indicators such as greenhouse gas emissions, depletion of non-renewable natural resources, etc.

In order to promote the value of eco-friendly cleaning products, the "academy of green cleaning" was established by OPTICOM Ltd. OPTICOM Ltd. developed an environmental safety standard for retailers based on lifecycle analysis (resource consumption, waste management, use of safe chemicals, green procurement, etc.), together with the non-profit partnership "Environmental Union" [40]. Currently, the company OPTICOM Ltd. is implementing the project "re-paper cycling", which can be attended by any company that signed a contract for the supply of consumables and household goods, including environmentally friendly goods. The project is based on the principle of reverse logistics when a customer returns wastepaper to the supplier with the same transport delivering orders to the customer. Thus, the export of waste does not result in additional fuel consumption and, as a consequence, the "extra" emissions of greenhouse gases [41].

The important feature of all cases is that even large companies are building partnerships in order to improve waste management practices through pooling resources and the expertise of partners, exchanging best practices and influencing a larger audience. It shows that every economic agent can play several but not all roles in the waste management system, and they can seek to join efforts with other business companies, government bodies, small businesses, and NGOs. The latter play an important role in creating social support for the CE initiatives, although their efforts may still seem disintegrated and often small-scale. A number of projects based on the principles of social entrepreneurship were implemented recently, such as projects "Thank You!" in St. Petersburg, "the Charity Shop" in Moscow, and "Re-Clothes Cycling" in Chelyabinsk. The common goal of these projects is to turn good but unwanted things into a useful resource for other people. People bring clothes and other things to the special collection spots. Some of the clothing is donated to charity, some of the clothing is sold, and unusable clothing is recycled or disposed of. The net profit of organizations is used to finance social projects and support charitable organizations. 
To build partnerships in the field of CE principle implementation, business companies establish associations. Association "clean country" is the country's largest industry association of regional operators in the field of waste management, involving equipment manufacturers, investment companies, and experts. The members of the association are the largest investors who create the infrastructure of the waste management sphere almost from scratch ( $90 \%$ of the market). They build modern complexes under concession agreements and investment agreements. The main objective of the association "clean country" is to stimulate the development of the industry of treatment of solid waste and ensure the protection of the interests of members [42].

In 2019, in Russia, a new nonprofit organization emerged called Association Ruspro, which promotes the development of a circular economy in Russia and creates a national culture of separate waste collection. Members of the association are manufacturers and importers. The association already found potential partners for the organization of a separate waste collection system and signed contracts with processors; now there are 11, but in the future their number will increase to 20. The association includes AB InBev Efes, Coca-Cola HBC Russia, Danone, Nestlé, PepsiCo, Tetra Pak, and Unilever. Members of the association process more than 211 thousand tons of waste per year. Within the framework of the agreement between Ruspro association and the clean country association, the parties agreed on cooperation in the field of waste management, involving the introduction of best practices and technologies, consulting and methodological assistance, etc.

In addition to the main activities of the associations, they carry out information and educational activities to raise awareness of individuals and legal entities about the importance of waste disposal, as well as increase the level of social and environmental responsibility of individuals and legal entities in the treatment of waste, in addition to the formation of a culture of separate collection and disposal of waste [43].

The case study allowed us to complement the roles of waste management system stakeholders identified in the research studies of Kurian (2006), Heidrich, Harvey, and Tollin (2008), and Isa, Asaari, and (2006) [44-46]. Traditionally, researchers identify stakeholders and describe the roles they can play in the waste management system. We propose to identify the roles existing in the WMS so that each person or company can identify and further develop its roles, as shown in Table 4.

The list of roles can be further complemented with the further development of WMS. Every person/company is a part of WMS and performs at least one role, although most of the industry companies can take up to eight roles. WMS can be effective if all the roles are identified and distributed, whereby every stakeholder understands and takes on the relevant responsibility, which can be achieved only through a combination of obligatory and voluntary actions. There is no customer role in the system because all persons, as well as the future generations, are customers of sanitation improvement, decreasing the loss of resources, as well as contributing to cleaner air, water, and soil, a decrease in disease rate, and other improvements in the quality of life.

The composition of roles taken on by a specific company is the heart of its waste management strategy. It defines the scope of its responsibility and processes to be included in corporate WMS.

PJSC SIBUR, PJSC Gazprom, and RZD Holding follow the strategy of G/C/T/PS/E, which means they take on the roles of the generator, collector, transporter, processor, and educator. "OPTICOM" follows the strategy $\mathrm{PR} / \mathrm{C} / \mathrm{T} / \mathrm{PS} / \mathrm{E}$, which means it takes on the roles of producer, collector, transporter, processor, and educator. "Re-Clothes Cycling" follows the strategy C/PM, which means it takes on the roles of collector and promoter.

Corporate WMS consists of the firm's position vis-à-vis the environment and defines the firm's relationship with nature. It describes strategies for the use of resources and waste management and acceptable environmental impacts of the company's activities. Waste management strategies try to minimize long-term environmental damages by managing the company's inputs, throughput, and outputs. Just as the corporate "total quality management" demands attention to each stage of the design and production process, a "total waste management" perspective can optimize the performance of the total system (Table 5). 
Table 4. The roles and responsibilities of waste management system (WMS) stakeholders.

\begin{tabular}{|c|c|}
\hline $\begin{array}{c}\text { WMS Stakeholder } \\
\text { Role }\end{array}$ & Responsibility Assigned to the Role \\
\hline Producer (PR) & $\begin{array}{l}\text { A company that produces products that will become solid waste at the end of the lifecycle. The } \\
\text { best example is companies that produce packaging or home electronics. The responsibility of the } \\
\text { producer is to decrease the environmental impact of the product through different actions like the } \\
\text { usage of biodegradable materials or recycled materials or materials that could be recycled, } \\
\text { increasing the degree of product recyclability, product service time extension, etc. }\end{array}$ \\
\hline Generator $(G)$ & $\begin{array}{l}\text { Any person or a company producing waste. The industrial generator's responsibility includes } \\
\text { decreasing the amount of waste, collecting and sorting waste, handling waste processing, and/or } \\
\text { recycling/reuse of waste. The household generator's responsibilities include decreasing the } \\
\text { amount of waste, collecting and sorting waste, and reusing waste. }\end{array}$ \\
\hline Collector (C) & $\begin{array}{l}\text { A company or a person that collects the waste generated by other persons or companies. } \\
\text { Examples are street sweepers in the city or voluntary services cleaning the forests or river banks. } \\
\text { The responsibility of the collector is to sort waste and bring it to the official disposal site without } \\
\text { burning or burying. Case studies show evidence of high importance of this role in developing } \\
\text { countries }[47,48] \text {. }\end{array}$ \\
\hline Transporter $(\mathrm{T})$ & $\begin{array}{l}\text { A company that transports waste from the official or non-official disposal sites to the disposer or } \\
\text { processor companies. The responsibility of the transporter is to keep the waste sorted in the way it } \\
\text { was sorted before the transportation and also to prevent secondary pollution due to the intended } \\
\text { or unintended loss of waste. }\end{array}$ \\
\hline Disposer (D) & $\begin{array}{l}\text { A company that accumulates and stores the waste before its processing or without intention to } \\
\text { process. Landfills perform the role of the disposer. The responsibility of the disposer is to prevent } \\
\text { environmental impact in the process of waste storage. It can also include waste sorting } \\
\text { (segregating) or keeping the waste sorted in the way it was done by the collector or the generator. }\end{array}$ \\
\hline Processor (PS) & $\begin{array}{l}\text { A company that processes waste, including recycling. The responsibility of the processor is to } \\
\text { increase the level of processing to decrease the amount of waste left after processing, to use } \\
\text { technologies with low environmental impact, and to improve the quality of the recycled products. }\end{array}$ \\
\hline Educator (E) & $\begin{array}{l}\text { A person or a company (including non-governmental organizations (NGOs) and media) that } \\
\text { teaches waste management tools, principles, and practices to any stakeholders. The responsibility } \\
\text { of the educator is to use up-to-date information and relevant training tools to improve the } \\
\text { knowledge and skills of stakeholders to be used in WMS. }\end{array}$ \\
\hline Promoter (PM) & $\begin{array}{l}\text { A person or a company (including NGO and media) that promotes the ideas of waste } \\
\text { management, shares best practices, involves new participants in WSM, and organizes contests or } \\
\text { actions in support of WMS. The responsibility of the promoter is to disclose the up-to-date and } \\
\text { true information on WMS, granting full access for everybody to the actions or campaigns without } \\
\text { discrimination. The promoter does not use the promotion to garner unfair competition. }\end{array}$ \\
\hline Regulator (R) & $\begin{array}{l}\text { Government or municipal body that produces a strategy of WMS development and relevant } \\
\text { legislation for all WMS stakeholders. It can also be a company developing and introducing } \\
\text { sectoral standards in waste management. The responsibility of the regulators is to focus on } \\
\text { positive environmental, social and economic effects of legislation, create incentives for all } \\
\text { stakeholders to take on their responsibilities, provide necessary resources to support legislation, } \\
\text { monitor its results, and continuously improve legislation in accordance with changing situation. }\end{array}$ \\
\hline Inspector (I) & $\begin{array}{l}\text { A government or municipal body, NGO, or a private sector company making sure that WMS } \\
\text { processes are performed according to the legislation, contract terms, and funding rules. Inspectors } \\
\text { may or may not perform punitive functions. The responsibility of an inspector is to focus } \\
\text { inspection on environmental, social, and economic effects, to not engage in corrupt and unfair } \\
\text { inspecting practices, to seek assistance in WMS development, and to provide transparency and } \\
\text { accuracy of inspection results. }\end{array}$ \\
\hline Funder $(\mathrm{F})$ & $\begin{array}{l}\text { A company or a person providing funds to support WMS development, including infrastructure } \\
\text { development, education, and promotion actions. It could be an ordinary funder when no other } \\
\text { role is performed or an active funder when a company or a person invests funds, as well as } \\
\text { performs another role. The responsibility of a funder is to ensure that funds are efficiently used } \\
\text { according to the intended purpose, to not engage corrupt and unfair practices in allocating funds, } \\
\text { and to measure the efficiency of the funds used for WMS development purposes. }\end{array}$ \\
\hline
\end{tabular}


Table 5. Types of corporate WSM strategies.

\begin{tabular}{|c|c|c|c|}
\hline $\begin{array}{c}\text { Types of WSM } \\
\text { Strategies }\end{array}$ & Passive WMS & Preventive WMS & $\begin{array}{c}\text { Active WMS (Sustainable Development } \\
\text { Management) }\end{array}$ \\
\hline $\begin{array}{l}\text { Organization } \\
\text { activities }\end{array}$ & $\begin{array}{c}\text {-Purification of emissions and discharges, disposal of } \\
\text { waste at the end of the production and technological } \\
\text { cycle } \\
\text {-Compliance with pollution reduction procedures } \\
\text {-Compliance with the requirements of external } \\
\text { environmental reporting } \\
\text {-environmental service } \\
\text {-Emergency action plan }\end{array}$ & $\begin{array}{l}\text {-Preventing environmental pollution by } \\
\text { replacing technologies, raw materials, etc. } \\
\text {-Waste reduction } \\
\text {-Decreasing the amount of waste left after } \\
\text { processing } \\
\text {-Promoting the ideas of waste management, } \\
\text { sharing the best practices }\end{array}$ & $\begin{array}{l}\text {-Implementation of ecological certification } \\
\text { programs } \\
\text {-Disclosing the up-to-date and important } \\
\text { information on WMS } \\
\text {-Product lifecycle (cradle-to-grave) system } \\
\text { development } \\
\text {-Recognition of enterprise importance in the } \\
\text { flow of goods, raw materials, and energy }\end{array}$ \\
\hline $\begin{array}{l}\text { State supportive } \\
\text { measures }\end{array}$ & $\begin{array}{l}\text {-State environmental control, the establishment of } \\
\text { effective standards, taking into account the real } \\
\text { technological and financial possibilities, taking into } \\
\text { account industry production parameters (for specific } \\
\text { industries and agriculture) } \\
\text {-Timely informing of a possible tightening of } \\
\text { environmental regulations, strict enforcement measures }\end{array}$ & $\begin{array}{c}\text {-Legislative increase of responsibility of top } \\
\text { managers and enterprises } \\
\text {-Requirements for integration into the regional } \\
\text { waste management system } \\
\text {-Mandatory provision of environmentally } \\
\text { relevant information to the public } \\
\text {-Development of incentive programs for energy } \\
\text { conservation. }\end{array}$ & $\begin{array}{l}\text {-Discussion and adoption of initiatives in the } \\
\text { field of health, environmental safety, and } \\
\text { sustainable development at the international } \\
\text { level as priorities in relation to the system of free } \\
\text { exchange of goods } \\
\text {-Strategies for managing and optimizing of the } \\
\text { flow of goods, raw materials, and waste }\end{array}$ \\
\hline
\end{tabular}


WMS business strategies seek to eliminate emissions, effluents, and waste reduction. Passive WMS shows that organizations abide by the existing environmental laws, standards, and regulations. The active WMS strategy is focused on the fact that the contradictions between the economy and environmental protection are resolved, and environmental imperatives are considered as an opportunity to change the product or technology, to improve the level of competence of personnel, etc. The choice of the type of WMS strategy is mainly related to the willingness of the company to make organizational changes and the willingness to resolve the contradiction between environmental and economic interests.

\section{Conclusions}

The investigation of the history of state regulation of waste management in Russia allowed us to identify four stages of its development between 1970 and 2019. Although the traditions of waste collection and processing rooted in the Soviet practices are rather strong in Russia in both industry and household practices, the crisis of the 1990s disrupted not only the technologies but also the culture of waste collection and processing. The reforms in this field started in 2004 and brought the concept of recycling instead of landfilling into regulatory space as a result of several stages of the reform.

The new stage of waste management development in Russia introduces ideas of responsible production and consumption, where the best approach to reduce waste is to consume less with higher efficiency. Circular economy in Russia is being developed in three major areas: (1) management of existing landfills and dumpsites; (2) optimization of MSW systems for future waste, specifically at the stage of collection, in order to increase waste recovery; (3) adoption of cleaner production patterns at the company level with the use of renewable technologies and materials (wherever possible); (4) introducing circular economy education at school and university levels.

The decentralized waste management ecosystem is under construction. In this ecosystem, all stakeholders share the responsibility for collecting, processing, and recycling solid waste. Stakeholders are the federal government, municipal administrations, households, businesses, and new stakeholders-regional operators and eco-industrial parks. The government offers regulation, infrastructure development funding, and financial incentives for other stakeholders. Municipal administration is in charge of waste management in local communities. Businesses are in charge of collecting and processing solid waste and promoting recycling practices. Households are in charge of separate waste collection. Regional operators are in charge of controlling all methods of waste management from a garbage tank to the range or plant on processing. Eco-industrial parks will be created to support green start-up following the 3R principles. As indicated in Reference [49], the new approach could reduce or remove the negative externalities that bad waste management entails, as well as create a new and more sustainable production model that can serve as a reference in all productive sectors of the Russian economy.

A key to successful implementation is the acceptance of the policy and the participation of the public. The policy process, therefore, needs to be transparent, and public participation needs to be organized and supported by information, consultation, and educational activities.

Consequently, we see this as the beginning of recycling regulation development in Russia. Only time will reveal the workability and effectiveness of the 2014 waste management law and a new 2019 system of handling MSW.

Author Contributions: Conceptualization, E.G., O.F., and N.V.; methodology, N.V.; data collection and formal analysis, O.F.; investigation, E.G. and O.F.; resources, O.F. and N.V.; writing-original draft preparation, O.F.; writing-review and editing, N.V. and E.G.; visualization, O.F.

Funding: This research received no external funding. The APC was funded by Bauman Moscow State Technical University.

Conflicts of Interest: The authors declare no conflict of interest. 


\section{References}

1. Food and Agriculture Organization (FAO). Guidelines for the Integration of Sustainable Agriculture and Rural Development. The concept of SARD. 2002. Available online: http://www.fao.org/docrep/w7541e/ w7541e04.htm (accessed on 19 July 2019).

2. Reh, L. Process engineering in circular economy. Particuology 2013, 11, 119-133. [CrossRef]

3. Birat, J.-P. Life-cycle assessment, resource efficiency and recycling. Met. Res. Technol. 2015, 112, 206. [CrossRef]

4. Von Bertalanffy, L. An Outline of General System Theory. Br. J. Philos. Sci. 1950, 1, 134-165. [CrossRef]

5. Boulding, K. The economy of the coming spaceship earth. In Environmental Quality in a Growing Economy; Jarrett, H., Ed.; Resources for the Future/Johns Hopkins University Press: Baltimore, MD, USA, 1966; pp. 3-14.

6. Pearce, D.W.; Turner, R.K. Economics of Natural Resources and the Environment, Italian ed.; Bologna, M., II, Ed.; Harvester Wheatsheaf: Hemel Hempstead, London, UK, 1990.

7. Erkman, S. Industrial ecology: An historical view. J. Clean. Prod. 1997, 5, 1-10. [CrossRef]

8. Chiu, A.S.; Yong, G. On the industrial ecology potential in Asian Developing Countries. J. Clean. Prod. 2004, 12, 1037-1045. [CrossRef]

9. Andersen, M.S. An introductory note on the environmental economics of the circular economy. Sustain. Sci. 2007, 2, 133-140. [CrossRef]

10. Mathews, J.A.; Tan, H. Progress towards a circular economy: The drivers and inhibitors of eco-industrial initiative. J. Ind. Ecol. 2011, 15, 435-457. [CrossRef]

11. Ellen Macarthur Foundation. 2012. Towards the Circular Economy. Available online: http://www. ellenmacarthurfoundation.org/business/reports (accessed on 21 April 2019).

12. The Circularity Gap Report "Closing the Circularity Gap in a 9\% World 2019". Available online: https: //docs.wixstatic.com/ugd/ad6e59_ba1e4d16c64f44fa94fbd8708eae8e34.pdf/ (accessed on 17 May 2019).

13. Golinska, P.; Kosacka, M.; Mierzwiak, R.; Werner-Lewandowska, K. Grey decision making as a tool for the classification of the sustainability level of remanufacturing companies. J. Clean. Prod. 2015, 105, 28-40. [CrossRef]

14. Küçüksayraç, E.; Keskin, D.; Brezet, H. Intermediaries and innovation support in the design for sustainability field: Cases from the Netherlands, Turkey and the United Kingdom. J. Clean. Prod. 2015, 101, 38-48. [CrossRef]

15. George, A.L. Case studies and theory development: The method of structured, focused comparison. In Diplomacy: New Approaches in History, Theory, and Policy; Lauren, P.G., Ed.; Free Press: New York, NY, USA, 1979; pp. 43-68.

16. Tyshenko, M.; Waste Ranking. Whats's going on with the waste in Russia and in the world. Available online: https://republic.ru/posts/90408 (accessed on 18 May 2019).

17. Kaza, S.; Yao, L.; Bhada-Tata, P.; Van Woerden, F. What a Waste 2.0: A Global Snapshot of Solid Waste Management to 2050; World Bank Urban Development: Washington, DC, USA, 2018; Available online: https://openknowledge.worldbank.org/handle/10986/30317License:CCBY3.0IGO (accessed on 17 June 2019).

18. Preston, F.; Chatham, J.L. House Briefing A Wider Circle? The Circular Economy in Developing Countries. Available online: https://reader.chathamhouse.org/wider-circle-circular-economy-developing-countries\#thecircular-economy (accessed on 17 April 2019).

19. Official Web-Site of Federal Service for Supervision of Nature Management (Rosprirodnadzor). Available online: http://rpn.gov.ru/ (accessed on 17 April 2019).

20. Russia: There Will Be a Change. Global Recycling. Available online: https:/global-recycling.info/archives/ 1023 (accessed on 30 May 2019).

21. What Is Solid Waste and How to Treat Them. Available online: https://vtorothody.ru/othody/tko.html (accessed on 30 March 2019).

22. Arkharov, I.A.; Simakova, E.N.; Navasardyan, E.S. Landfill gas as feedstock for energy and industrial processes. Chem. Pet. Eng. 2016, 52, 7-8. [CrossRef]

23. Eurostat. Treatment of Waste. Available online: http://appsso.eurostat.ec.europa.eu/nui/show.do?dataset= env_wastrt\&lang=en (accessed on 30 March 2019). 
24. Semiletov, V.P. Issues of Economic Planning of Education and the Use of Secondary Material Resources. Ph.D. Thesis, Research Institute in Economics of State Planning Agency of Ukrainian Soviet Socialist Republic, Kiev, Ukraine, 1984.

25. Utkin, E.A. Use of secondary resources: Experience of fraternal countries // Economics and Organization of Production. Know. Publ. House. 1987, 8, 64.

26. Resolution of the Government of the Russian Federation of 13 September 1996 No. 1098 “On the Federal target Program Waste". Available online: https://base.garant.ru (accessed on 17 April 2019).

27. Federal Law of 24 June 1998 N 89-FZ “On Production and Consumption Waste” (as Amended). Available online: https://base.garant.ru (accessed on 17 April 2019).

28. Federal Law "On Amendments to the Federal Law "On Production and Consumption Waste" and Certain Legislative Acts of the Russian Federation" Dated 31 December 2017 N 503-FZ. Available online: http: //www.consultant.ru/document/cons_doc_LAW_286766/ (accessed on 23 April 2019).

29. Order of the Government of the Russian Federation No84-r from 25 January 2018. Available online: http://static.government.ru (accessed on 23 April 2019).

30. Pavlenkov, M.N.; Larionov, V.G.; Voronin, P.M. Approach to predictive modelling of total municipal solid waste removal volumes. Biofuels 2017, 8, 373-376. [CrossRef]

31. Pavlenkov, M.N.; Larionov, V.G.; Voronin, P.M.; Pavlenkov, I.M. Specifics of monitoring municipal investment projects in the municipal solid waste industry. Espacios 2017, 38, 14.

32. Pavlenkov, M.N.; Larionov, V.G.; Voronin, P.M. The Method for Evaluation and Selection of Investment Projects in the Field of Municipal Waste Management. Indian J. Sci. Technol. 2016, 9, 151-155. [CrossRef]

33. Municipal Solid Waste Management: Opportunities for Russia. Summary of Key Findings. Available online: https://www.ifc.org/wps/wcm/connect/a00336804bbed60f8a5fef1be6561834/PublicationRussiaRREPSolidWasteMngmt-2012-en.pdf?MOD=AJPERES (accessed on 23 April 2019).

34. Remchukov, M.K. Sibur-Green Strategy. Implementation of Circular Economy principles in Russia. Round Table “Transition to Circular Economy in Russia" 11 October 2018. Available online: http://www.anspa.ru/ linkpics/News/SIBUR.pdf (accessed on 12 May 2019).

35. Environmental Policy of GSC Gazprom. Available online: http://www.gazprom.ru/nature/ecology/ (accessed on 12 May 2019).

36. Environmental Strategy of JSC RZD until 2017 and with the Forecast till 2030. Available online: http: //www.rzdctares.ru/ (accessed on 17 May 2019).

37. RZD Placed Green Eurobonds for 500 Million Euro. TASS. Available online: https://finance.rambler.ru/ markets/42189010/?utm_content=rfinance\&utm_medium=read_more\&utm_source=copylink (accessed on 17 May 2019).

38. Resource Saving of "KHMAO" Placed a Debut Bond Issue for 1.1 Billion Rubles Vedomosti, 19 December 2018. Available online: https:/www.vedomosti.ru/business/articles/2019/05/08/801079-rossiiskaya-kompaniyavpervie (accessed on 17 May 2019).

39. Rational Waste Management. Evraz Sustainable Development Report 2018. Available online: https: //sr2018.evraz.com/ru/hse/environmental-stewardship/waste-stewardship (accessed on 10 October 2019).

40. Official Web-Site of OPTIKOM Company. Available online: https://www.opti-com.ru/ (accessed on 17 May 2019).

41. Sharing Economy in Russia in 2017. Russian Association of Electronic Communication. Available online: https://raec.ru/activity/analytics/9845/ (accessed on 8 May 2019).

42. Clean Country Association. Official Web-Site. Available online: https://www.cleancountry.ru/ (accessed on 12 October 2019).

43. RusPro Association. Official Web-Site. Available online: https://ruspro.org/ (accessed on 12 October 2019).

44. Kurian, J. Stakeholder participation for sustainable waste management. Habitat Int. 2006, 30, 863-871. [CrossRef]

45. Heidrich, O.; Harvey, J.; Tollin, N. Stakeholder analysis for industrial waste management systems. Waste Manag. 2008, 29, 965-973. [CrossRef] [PubMed]

46. Isa, M.H.; Asaari, F.A.; Ramli, N.A.; Ahmad, S.; Siew, T.S. Solid waste collection and recycling in Nibong Tebal, Penang, Malaysia: A case study. Waste Manag. Res. 2005, 23, 565-570. [CrossRef] [PubMed]

47. Pincelli, I.P.; Meireles, S.; de Castilhos, A.B., Jr. Socio-productive Inclusion of Waste Pickers on Segregated Solid Waste Collection in Brazilian Universities as an Instrument for Sustainability Promotion June 2019. 
In Sustainability on University Campuses: Learning, Skills Building and Best Practices; Springer International Publishing: Berling, Germany, 2019. [CrossRef]

48. Rai, R.K.; Bhattarai, D.; Neupane, S. Designing Solid Waste Collection Strategy in Small Municipalities of Developing Countries Using Choice Experiment Journal of Urban Management // Journal of Urban Management, January 2019. Available online: https://www.sciencedirect.com/science/article/pii/ S2226585617301188?via\%3Dihub (accessed on 20 September 2019).

49. Salguero-Puerta, L.; Leyva-Diaz, J.C.; Cortes-Garcia, F.J.; Molina-Moreno, V. Sustainability indicators concerning waste management for implementation of the circular economy model on the University of Lome (Togo) Campus. Int. J. Environ. Res. Public Health 2019, 16, 2234. [CrossRef] [PubMed]

C 2019 by the authors. Licensee MDPI, Basel, Switzerland. This article is an open access article distributed under the terms and conditions of the Creative Commons Attribution (CC BY) license (http://creativecommons.org/licenses/by/4.0/). 